\section{Former German APSA Congressional Fellows Meet in Bonn}

\section{Claus Gramckow (Class of 1986), Friedrich-Naumann Foundation}

On December 16-17, 1994, 16 German Congressional Fellows met in Bonn for their second reunion. Since 1983, the German Marshall Fund and, in the initial stages, the American Council on Germany have sponsored two Germans each year to participate in the American Political Science Association's Congressional Fellowship Program. The meeting started with an official reception at the residence of Prof. Dr. Werner Weidenfeld, the coordinator for German-American Cooperation. In his remarks, Weidenfeld spoke about the state of GermanAmerican relations and the German government's efforts to meet the challenges presented by the changes occurring after the end of the Cold War. He acknowledged the program as an important step towards the better understanding of German and American politics on both sides of the Atlantic. Peter Weitz, the director of programs of the German Marshall Fund, attended the reception and emphasized how pleased the fund is with the success of the program and the positive impact it has had on the participants.

The next morning, the Fellows met at the Bundestag and toured the newly renovated Parliamentary Building. Afterwards, the group met with Mr. Stöcker, director of the American Desk at the German Foreign Ministry, and Mr. J.D. Bindenagel, the Deputy Chief of Mission at the US-Embassy in Bonn. Bindenagel had been an APSA Congressional Fellow in 1987. This roundtable discussion, which centered on the future of German-American Relations, was a lively exchange of opinions that extended through lunch and lasted long into the afternoon.

The last part of the program was dedicated to a discussion of the possibility of a German Congressional Fellow alumni organization. The group decided to found an informal organization called the German APSA Congressional Fellows
Alumni. The purpose of this organization will be to keep members in contact with one another, to assist new fellows, to lobby for the extension of the German participation to a full year and to promote the importance of this program in Germany. They also decided to publish an internal newsletter about the activities of the fellows and agreed to meet every two years starting with the weekend before Christmas 1996 in Frankfurt.

The meeting concluded with a dinner during which old friendships were renewed and new ones were created. The participants exchanged many fond memories of their experience on Capitol Hill and emphasized how valuable this program had been for their lives and careers. This group is a unique and exceptional resource on the U.S. political decision-making system that is not necessarily used effciently by the appropriate institutions in Germany. The group plans to address this last issue in the years ahead. A special thank you goes to the German Marshall Fund for sponsoring the alumni meeting.

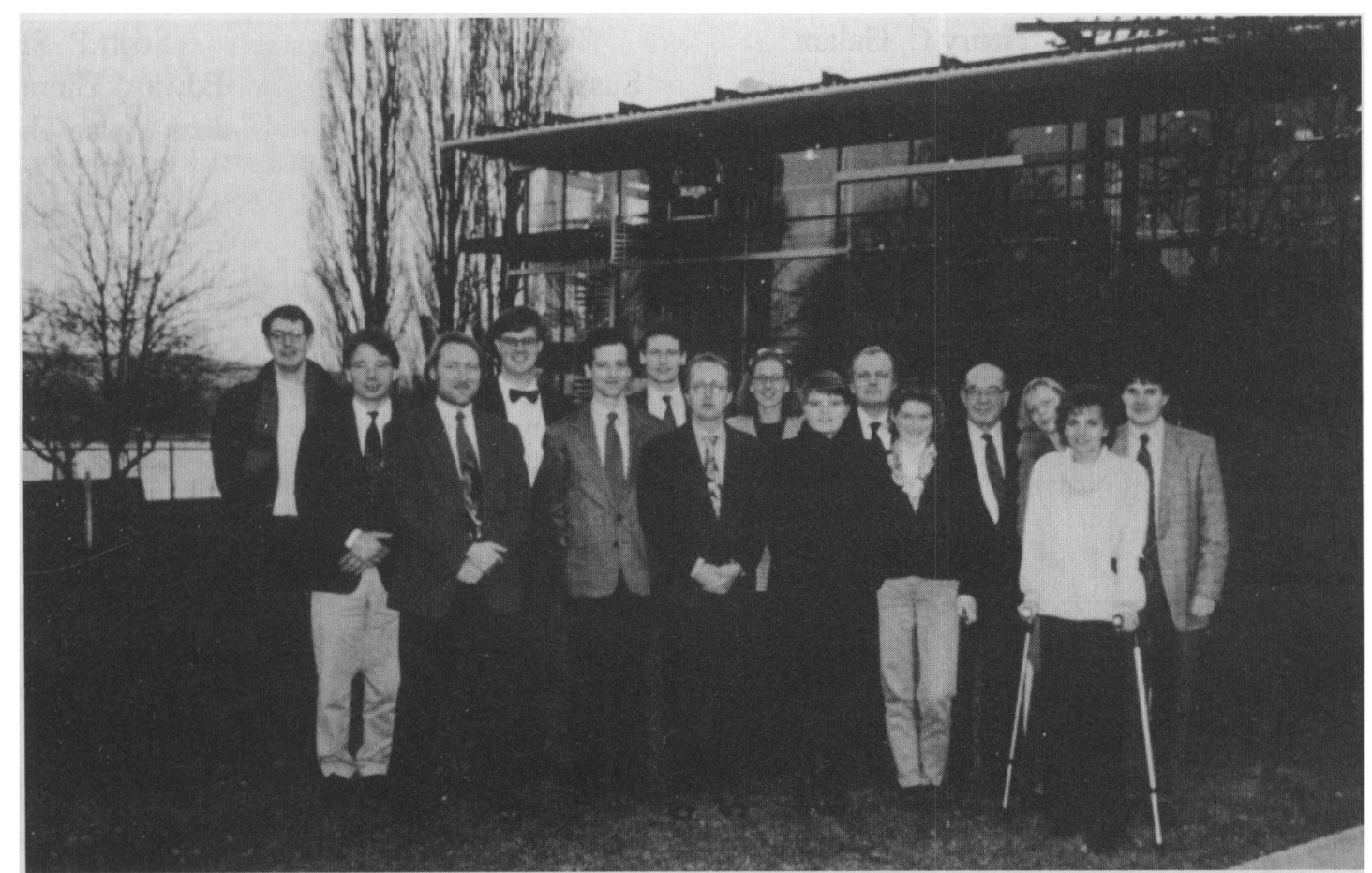

Picture with German Congressional Fellows in front of the German Parliaments Building in Bonn (from lett to right) Jürgen Wilzewski, Peter Rudolf, Jochen Christe, Wolfgang Drechsler, Stefan von Senger, Bernd Fußy, Reinhard Kowalewsky, Julia Monar, Karin Matussek, Claus Gramckow, Annette Kofler, Kurt Shell, Armgard von Reden, Sabine Gans, Martin Thunert 